\title{
The Effect of Investment Promotion on Foreign Direct Investment Inflow into Ghana
}

\author{
Justice G. Djokoto \\ Department of Agribusiness, Central Business School, Central University College \\ P. O. Box DS 2310, Dansoman, Accra, Ghana \\ Tel: 233-28-503-7399 E-mail:dgameli2002@gmail.com
}

Received: January 10, 2012

Accepted: February 15, 2012

Published: March 1, 2012

doi:10.5539/ibr.v5n3p46

URL: http://dx.doi.org/10.5539/ibr.v5n3p46

\begin{abstract}
The paper investigated the effect of investment promotion (IP) on foreign direct investment flow (FDI) into Ghana. Cointegration among the variables was established using auto regressive distributed lag (ARDL) models in the presence of a mix of I (0) and I (1) variables. The control variables, inflation and trade openness were statistically significant in the short run. Whilst inflation exerted a negative effect on FDI inflow; trade openness positively induced FDI inflow. GDP per capita and exchange rate did not statistically significantly influence FDI inflow in the short run. In respect of the key variable GIPC, in the short run, there was a positive but statistically insignificant effect on FDI inflow. The estimated long-run ARDL model showed that macroeconomic variables such as inflation, GDP and trade openness determined FDI inflow into Ghana. Notwithstanding the positive relationship between establishment of IP agency (GIPC) and FDI inflow, this relationship was statistically insignificant. Greater efforts at macroeconomic management specifically, promotion of external trade, increasing GDP and reducing inflation holds more promise to attracting FDI into Ghana. GIPC should be maintained to provide a supportive role when the foreign investors arrive in Ghana.
\end{abstract}

Keywords: Foreign direct investment, Investment promotion, Trade openness, Inflation, Gross domestic product

\section{Introduction}

\subsection{Background}

In recent years debate on the role of external resource inflows, including foreign direct investment (FDI) and their potential contribution to accelerating growth and progress towards reaching development goals in Africa has taken centre stage (UNECA, 2006). In line with the general trend of private capital flows in developing regions, FDI to Africa has been on the rise in recent years especially since the 1990s (Ndikumana, 2003; UNECA, 2006). FDI which refers to an investment made to acquire lasting interest in an enterprise operating outside of the economy of the investor (UNCTAD, 2002) is noted for the following benefits (de Mello Jr., 1997); Firstly, inward FDI can stimulate local investment by increasing domestic investment through links in the production chain when foreign firms buy locally made inputs or when foreign firms supply intermediate inputs to local firms. Secondly, the foreign capital inflow augments the supply of funds for investment thus promoting capital formation in the host country. Thirdly, inward FDI can increase the host country's export capacity causing the developing country to increase its foreign exchange earnings. Fourthly, FDI is also associated with new job opportunities and enhancement of technology transfer, and boosts overall economic growth in host countries.

A portfolio of activities through which governments aim to attract foreign direct investment (FDI) inflows constitutes investment promotion (Wells \& Wint, 2000). These portfolio of activities include: advertising, investment seminars and missions, participation in trade shows and exhibitions, distribution of literature, one-to-one direct marketing efforts, facilitating visits of prospective investors, matching prospective investors with local partners, help with obtaining permits and approvals, preparing project proposals, conducting feasibility studies and servicing investors whose projects have already become operational. Some Investment Promotion Agencies (IPAs) do engage in granting incentives to foreign investors, screening potential investment projects and negotiations with foreign investors, yet Wells and Wint (2000) excludes these from there operationalisation of investment promotion. Harding and Javorcik (2011) categorised investment activities into four: 1. national image building, 2. investment generation, 3. investor servicing, and 4. policy advocacy. Image building activities gear towards building a perception of the country as an attractive location for foreign direct investment. Identifying potential investors who 
may be interested in establishing a presence in the country, developing a strategy to contact them and starting a dialogue with the purpose of having them commit to an investment project constitutes investment generation. The third group, investor servicing encompasses assisting committed investors in analysing business opportunities, establishing a business and maintaining it. Policy advocacy involves initiatives leading to improving the quality of the investment climate and identifying the views of private sector in this area.

Two broad strategies are identifiable in investment promotion: targeting (focusing on priority arrears) and attracting all kinds of investment (mass approach). The latter strategy will require IPAs staff to participate in many different types of fairs and promote the country as a good place to do business. On the contrary, targeting, which investment promotion practitioners believe to be a better strategy (Harding \& Javorcik, 2011) requires participation in fairs that are specific to the industries it targeted. Additionally, the IPA emphasises why its country is an ideal location for investors operating in the targeted areas. The idea behind targeting is that a more focused message tailored and delivered to a narrow audience is more effective than general investment promotion activities.

\subsection{Profile of Ghana Investment Promotion Centre}

Ghana's investment promotion agency is Ghana Investment Promotion Centre (GIPC). Established in 1994, under legal instrument Act 478, aims at reducing obstacles to and creating incentives to FDI (Cotton \& Ramachandran, 2001; Aryeetey, et al, undated). The incentives accompanying the law included: depreciation of the capital allowance of $75 \%$ of capital expenditure incurred in the year of investment and in subsequent years, the free transferability of profits and dividends and foreign exchange retention accounts through which all foreign payments including dividends can be made. Others were exemption from payment of customs duties on machinery and plant for the establishment of mines and further relief for selected items for on-going mining projects, and the establishment of well-defined rules for dispute settlement.

The Act 478 (1994) which was hailed as the best in Africa (UNCTAD, 2003) resulted in the following specific objectives and functions of the Centre (GIPC, 2011):

- Initiating and supporting measures that will enhance the investment climate in the country for both Ghanaian and non-Ghanaian companies.

- Promoting investments in and outside Ghana through effective promotion.

- Collecting, collating, analysing and disseminating information about investment opportunities and sources of investment capital, and advising on the availability, choice or suitability of partners in joint-venture projects.

- Registering and keeping records of all enterprises to which this Act is applicable.

- Identifying specific projects and inviting interested investors for participation in those projects initiating, organising and participating in promotional activities such as exhibitions, conferences and seminars for the stimulation of investments.

- Maintaining a liaison between investors and ministries, government departments and agencies, institutional lenders and other authorities concerned with investments.

- Providing and disseminating up-to-date information on incentives available to investors.

- Assisting investors by providing support services including assistance with permits required for the establishment and operation of enterprises.

- Evaluating the impact of the Centre on investments in the country and recommending appropriate changes where necessary.

- Registering and keeping records of all technology-transfer agreements relating to investments under this Act.

- Performing such other functions as are incidental to the attainment of the objectives of this Act.

In furtherance of these objectives and functions, GIPC offers the following services: investment facilitation, monitoring and evaluation, handling investment procedures, assessing cost of doing business in Ghana, examining the investment environment and facilitating infrastructure for investment in Ghana. Prior to the 1994 enactment to establish the GIPC, various legal instruments were activated ostensibly to promote both domestic and foreign investment. These were Investment Act (Act 172) of 1963, Investment Decree of 1973 (NRCD 141), Investment Policy Decree of 1975 (NRCD 329), Investment Code of 1981 (Act 437) and Investment Code 1985 (PNDCL 116). These though had promotion objectives were more regulatory in nature. Indeed, these fell short of expectation as investment promotion instruments (Aryeetey \& Baah-Boateng, 2007). 


\subsection{Problem Statement}

Harding and Javorcik (2011) studying information asymmetries between host countries and potential foreign investors found some interesting results: 1. that investment promotion efforts lead to higher FDI inflows. 2. Investment promotion efforts seemed more effective in countries where a lower share of the population speaks English, in countries which are more culturally distant from the US and in countries where obtaining construction permits takes longer. 3. Splitting the sample into developed and developing economies, they found that investment promotion had a positive impact on FDI inflows in the developing economies but not in developed economies. 4 . Within the subsample of developing countries, investment promotion is more effective in host countries where English is not widely spoken, the cultural distance to the US is larger and obtaining construction permits is more burdensome. Ghana has regulated investment until 1994 when a law was passed to transform the investment regulating agency (Ghana Investment Centre) into an investment promotion agency (Ghana Investment Promotion Centre, GIPC). Secondly, Ghana, a former colony of the UK, uses English as an official language but has focused largely on English speaking countries to attract FDI. Indeed, it has a smaller cultural distance with US and many European countries. Thirdly, Ghana is not included in the set of developed economies. Therefore, what is the effect investment promotion on FDI inflow into Ghana?

\subsection{Objectives}

The objective of the paper is to assess the effect of investment promotion on FDI inflows into Ghana.

\subsection{Relevance}

Governments have recognised the need to be innovative and efficient in responding to the concerns and expectations of investors, while striving contemporaneously to optimise the benefits of FDI for their national economies (Ögütçü, 2002). Thus linking the promotion of FDI to local economies has become a matter of great importance to governments all over the world. Also, Morisset (2003) notes very little is known about what IPAs have been really doing, notably in emerging economies, and whether they have been effective in influencing investors' decisions. Thus an assessment of their effect especially for Ghana, a developing economy is in the right direction.

\subsection{Organisation}

The rest of the paper is organised into 5 sections. Section 2 presents the review of literature pertinent to the subject. Section 3 presents the model and data fitted to it. The results are presented and discussed in section 4 with conclusions and distilled recommendations captured in section 5 .

\section{Literature Review}

\subsection{Theoretical Review}

Dunning (1977) and Dunning (1988) theorise about FDI and provided bases for what is known as Dunning's Eclectic paradigm. The paradigm states that, the extent, geography, and industrial composition of foreign production undertaken by Multinational Enterprise (MNE) is determined by the interaction of three sets of interdependent variables which, themselves, comprise the components of three sub-units (Dunning, 2001). The mathematical function is:

$$
F D I=f(O, L, I)
$$

where, $\mathrm{O}$ is ownership, $\mathrm{L}$ is location and $\mathrm{I}$ is internalisation.

Ownership, location, and internationalisation are key competitive advantages in this paradigm. The ownership competitive advantage posits that, all other factors unchanged, the greater the competitive advantages of the investing firms, relative to those of other firms the more they are likely to be able to engage in, or increase, their foreign production (Dunning, 2001). The locational attractions, avers that the more the immobile, natural or created endowments, needed by the firms to use jointly with their own competitive advantages, favour a presence in a foreign, rather than a domestic, location, the more firms will choose to supplement or take advantage of their ownership specific advantages by engaging in FDI. For this reason, the MNEs would undertake activities so as to add value to their operations. The final competitive advantage which is internalisation, which offers a framework for evaluating alternative ways in which firms may organise the creation and exploitation of their core competencies, given the locational attractions of different countries or regions. Such modalities range from buying and selling goods and services in the open market, through a variety of inter-firm non-equity agreements, to the integration of intermediate product markets and an outright purchase of a foreign corporation. In summary, the eclectic paradigm, like its near relative, internalisation theory, asserts that the greater the net benefits of internalising cross-border intermediate product markets, the more likely a firm will prefer to engage in foreign production itself, rather than 
license the right to do so, for example by a technical service or franchise agreement, to a foreign firm (Dunning, 1993).

\subsection{Empirical Review}

In recent times the role of Investment Promotion Agencies (IPAs) has been highlighted and undergirded with empirical evidence. Establishing an IPA became a central part of most countries' development strategies with over 160 investment promotion agencies worldwide (UNCTAD, 2001). Morisset (2003) investigated the relationship between FDI inflow in the presence of country's investment climate and market size. Using data from a survey on 58 countries, it was found that greater investment promotion was associated with higher cross-country FDI flows. These findings were conditioned on three caveats: 1. the effectiveness of the IPA depended on the country's environment in which it operates. 2. The scope of activities that an IPA undertook influenced its performance. 3. Certain internal characteristics of the IPA were associated with greater effectiveness.

Harding and Javorcikr (2007) made similar findings using a more recent and larger dataset of 109. Specifically, they found that investment promotion efforts appeared to increase foreign direct investment inflows to developing countries. Additionally, IPA characteristics, such as its legal status and reporting structure, influenced the effectiveness of investment promotion. There was also evidence of diversion of foreign direct investment due to investment incentives offered by other countries in the same geographic region. These findings did not diverge when they compared results of two analytical approaches; firstly, testing whether economic sectors explicitly targeted by IPAs received more FDI in the post-targeting period relative to the pre-targeting period and non-targeted economic sectors; secondly, testing whether the existence of an IPA was correlated with higher foreign direct investment inflows.

Aside of the mere effect of the presence of an IPA on FDI inflow, some investigators have examined the effect of promotion expenditures on FDI inflow. One such study was presented by Kim et al (2003). Their study which was localised in the US unlike other cross-country studies, examined the effect of a state's financial incentives and state characteristics on FDI attraction. Applying a conditional logit model with FDI (new plants) as dependent variable to data from 1987-1994, they found that both promotion expenditures and agglomeration economies were important in attracting foreign plants. Promotion expenditures by states with small economies could partially offset location disadvantages of agglomeration (urbanisation and/or localisation) economies.

In an earlier study also on the US, Head et al (1999) using data from 1980-1992, assessed the effectiveness of US states promotion efforts in light of strong agglomeration effects in Japanese investment. The provision of foreign trade zones, lower taxes, and job-creation subsidies had statistically significant effects on the location of investment. Simulations showed that unilateral withdrawal of promotion would have caused individual states to lose substantial amounts of Japanese investment. However, because state promotional policies tended to offset each other, such actions on the geographic distribution of Japanese investment would have had miniscule effect.

There is some evidence in the literature on Ghana specific studies. Tsikata, et al (2000) studied the determinants of FDI in Ghana and categorised FDI flows to Ghana since 1983 into three phases namely; the period 1983-88, 1989-92 and 1993-96. The first period witnessed sluggish inflows, averaging about $\$ 4$ million per annum, and the highest and lowest inflows during the period being \$6 million in 1985 and \$2 million in 1984 respectively. The second, 1989-92 recorded moderate inflows averaging about $\$ 18$ million per annum the highest and lowest being \$22 million in 1992 and \$14.8 million in 1990 respectively. The third, 1993-96 was a period of significant, but oscillatory inflows, which peaked in 1994 at \$233 million, but fell by more than $50 \%$ the following year to \$107million. Tsikata et al (2000) described a three-way nexus of economic growth, investment and political stability, which had emerged since the coup d'etat of 1972. In that year, a growth rate of $2.3 \%$ was recorded, accompanied by a more than $60 \%$ drop in FDI (from \$30.6 million in 1971 to $\$ 11.5$ million in 1972). In 1979 when Rawlings took power and was perceived as anti-business, growth fell to as low as $-3.2 \%$; there was also an outflow of $\$ 2.8$ million of FDI. The state of the economy worsened further in his second advent that is from a negative growth rate of $3.5 \%$ in 1981 to $-6.9 \%$ in 1982; however, inflow of FDI remained constant at $\$ 16.3$ million. The relationship emerged again when a parliamentary democracy replaced the military junta in 1992 . The rate of growth of $5.3 \%$ in 1991 fell to $3.9 \%$ in 1992 . This had been previously attributed to deficit financing undertaken in the democratisation process. The FDI flow however, increased from \$20 million in 1991 to \$22.5 million in 1992.

Barthel et al (2008) identified access to land, property registration, labour market (regulations, availability of skilled labour, labour productivity) and political instability as factors inhibiting FDI flows into Ghana. Following these findings, they recommended the following: speeding up of reforms in land administration and property registration; GIPC liaising with labour unions and the labour commission to make labour unions more business friendly; 
Government focusing on few subsectors in manufacturing such as agro-processing and food and beverages; and making education more functional.

In investigating the short-run and long-run relationship between external merchandise agricultural trade and FDI inflows into agricultural sector of Ghana, using Toda-Yamamoto augmented Granger Causality test, Djokoto (2012) arrived at the following conclusions: 1. In the short-run, the coefficient for FDI inflows and imports were statistically significant. The negative sign pointed to a substitution or replacing relationship between the two variables. 2. The coefficients between exports and FDI though negative, were not statistically significant. 3 . In the long-run, there was a feedback between imports and FDI. Exports caused FDI but not the reverse.

Dah and Khadijah (2010) established a positive relationship between FDI and locational attraction. Of the two components within the locational attraction, natural resource attracted more FDI than market size in the case of Africa. It was noted that through a case study of Angola, oil attracted FDI because oil was location attraction, which attracted foreign firms. These investments on the other hand contributed to the productive capacity of the receiving country thus stimulating economic development. They however noted that the availability of natural resources (oil) and its ability to attract foreign investment did not guarantee economic development. The establishment of appropriate institutions, mechanisms and policies would ensure efficient use of oil revenue for sustained economic growth.

Exchange rate had no discernible effect on Ghana's FDI (Nyarko, et al, 2011). This was possible by modelling the causal relationship between FDI inflows and exchange rate regimes over a 39 year period (1970-2008). Employing Ordinary Least Squares and the cointegration techniques, democracy was found to have the expected positive sign and to be a robust determinant of FDI in Ghana.

\section{Methodology}

\subsection{Model}

From the above review of the literature, the effect of IPAs on FDI inflow has been examined within the environment of a single equation. In some cases, the presence of the IPA was captured as a dummy (Harding \& Javorcikr, 2007) whilst in others the expenditure outlays on the IPAs were used (Kim et al, 2003). For want of rigour, demand for FDI is explicitly derived through constrained optimisation with the inclusion of other variables including a dummy for Ghana's IPA, GIPC.

Assuming, a cost function faced by a firm with both domestic and foreign production plants. A growth strategy would require the firm to decide whether to expand production domestically and export to a foreign market or invest directly in a foreign market. The option to locate in a foreign country may be viewed within the framework of horizontal integration. Faced with this choice, the firm would seek to minimise cost of production for the plants at home and abroad.

Considering the following relation,

$$
C=\omega_{d}\left(Q_{d}\right) Q_{d}+\omega_{f}\left(Q_{f}\right) Q_{f}
$$

where, $\mathrm{C}$ denotes total cost, $\omega_{d}$ and $\omega_{f}$ are unit costs in domestic plants and foreign plants, respectively, and $\mathrm{Q}_{d}$ and $\mathrm{Q}_{f}$ are respective quantities produced in each plant. Unit costs in both plants are a function of the quantity produced. There is a limitation on the production of the firm made of domestic and foreign output, given by:

$$
\bar{D}=Q_{d}+Q_{f}
$$

Consider an invitation to minimise cost of production in both plants subject to equation (3). The Lagrangean will be set up as in equation (4).

$$
L a=\omega_{d}\left(Q_{d}\right) Q_{d}+\omega_{f}\left(Q_{f}\right) Q_{f}+\lambda\left(\bar{D}-Q_{d}-Q_{f}\right)
$$

Taking partial derivative of 3 with respect to $\mathrm{Q}_{d}, \mathrm{Q}_{f}$ and $\lambda$ then setting each equation to zero, yields equations (5), (6) and (7).

$$
\begin{gathered}
\frac{\partial L a}{\partial Q_{d}}=\frac{d \omega_{d}}{d Q_{d}} Q_{d}+\frac{d \omega_{d}}{d Q_{d}}\left(Q_{d}\right)-\lambda=0 \\
\frac{\partial L a}{\partial Q_{f}}=\frac{d \omega_{f}}{d Q_{f}} Q_{f}+\frac{d \omega_{f}}{d Q_{f}}\left(Q_{f}\right)-\lambda=0
\end{gathered}
$$




$$
\frac{\partial L a}{\partial \lambda}=\bar{D}-Q_{d}-Q_{f}=0
$$

Since the firm's decision is to locate the foreign plant, equation (8) is derived for $\mathrm{Q}_{f}$.

$$
Q_{f}=\left(\frac{\frac{d \omega_{d}}{d Q_{d}}}{\frac{d \omega_{d}}{d Q_{d}}+\frac{d \omega_{f}}{d Q_{f}}}\right) \bar{D}+\left(\frac{1}{\frac{d \omega_{d}}{d Q_{d}}+\frac{d \omega_{f}}{d Q_{f}}}\right)\left(\omega_{d}-\omega_{f}\right)
$$

where:

$$
\left(\frac{\frac{d \omega_{d}}{d Q_{d}}}{\frac{d \omega_{d}}{d Q_{d}}+\frac{d \omega_{f}}{d Q_{f}}}\right) \text { and }\left(\frac{1}{\frac{d \omega_{d}}{d Q_{d}}+\frac{d \omega_{f}}{d Q_{f}}}\right) \text { are assumed to be positive. }
$$

The positive coefficients in equation (8) suggest that the output churned out in the foreign firm has a positive relationship with total demand $\bar{D}$ and differences in unit costs. Consequently, if $\omega_{d}>\omega_{f}$, the foreign plant increases its production in foreign firm. On the other hand if $\omega_{d}<\omega_{f}$, then, the firm will expand production in its domestic plant, resulting in a reduction in the output produced in its foreign plant. Having determined the desired output, the firm must decide quantities of inputs to be used for the production in the foreign firm. Admittedly, several inputs go into production processes. However, for brevity, two inputs are assumed; labour, L and capital, K. Thus the cost of producing the $\mathrm{Q}_{f}$, denoted as $\mathrm{C}_{f}$ is shown in equation (9).

$$
C_{f}=w L+k K
$$

Where, $w$ and $k$ are wage rate and cost of capital respectively. The subscript for foreign firm ${ }_{f}$ is dropped subsequently. Assuming a Cobb-Douglas production function;

$$
Q=L^{a} K^{b}
$$

the Lagrangean is set up as in equation (11). Unlike in equation (4), the constraint is the production function.

$$
L a=w L-k K+\lambda\left(Q-L^{\alpha} K^{\beta}\right)
$$

Taking first order partial derivatives with respect to $w, k$ and $\lambda$, and equating to zero results in equation (12), (13) and (14) respectively.

$$
\begin{aligned}
& \frac{\partial L a}{\partial L}=w-\lambda \alpha\left(\frac{Q}{L}\right)=0 \\
& \frac{\partial L a}{\partial K}=k-\lambda \beta\left(\frac{Q}{K}\right)=0 \\
& \frac{\partial L a}{\partial \lambda}=Q-L^{\alpha} K^{\beta}=0
\end{aligned}
$$

Solving for K and substituting Q from equation (8) results in equation (15).

$$
K=\left[\left(\frac{\beta}{\alpha}\right)\left(\frac{w}{k}\right)\right]^{\alpha /(\alpha+\beta)}\left[\left(\frac{\frac{d \omega_{d}}{d Q_{d}}}{\frac{d \omega_{d}}{d Q_{d}}+\frac{d \omega_{f}}{d Q_{f}}}\right) \bar{D}+\left(\frac{1}{\frac{d \omega_{d}}{d Q_{d}}+\frac{d \omega_{f}}{d Q_{f}}}\right)\left(\omega_{d}-\omega_{f}\right)\right]^{1 /(\alpha+\beta)}
$$

Therefore, the capital stock $\mathrm{K}$ possesses a positive relationship with total demand (sum of domestic and foreign demand) and a negative relationship with the unit costs of foreign costs relative to domestic costs. Marchant et al 
(2002) following Bajo-Rubio and Sosvilla-Rivero (1994) took two important steps; firstly, substituted K with FDI and assumed demand to be GDP, and secondly, augmented the right hand side of equation (16) with the following variables: compensation (C), interest rates (IR), trade barriers (TB), exchange rates (ER), and exports (X). However, for the purposes of this paper, the variables will be replaced by determinants of FDI. The resulting model is given by 16.

$$
F D I=f(G D P, E R, T O P)
$$

Expressing equation (16) mathematically and taking the natural logarithms results in equation (17).

$$
\ln F D I_{t}=\gamma_{0}+\gamma_{1} \ln G D P_{t}+\gamma_{2} \ln E R_{t}+\gamma_{3} \ln T O P+\varepsilon_{t}
$$

Harding and Javorcikr (2007) found the following country control variables significant in both the total sample (world) and developing country sub-sample: GDP per capita, GDP growth, population and inflation. These explained country size. Restrictions on civil liberties were statistically indistinguishable from zero. Morisset (2003) used only GDP per capita to capture country size and found strong linear pairwise correlation among GDP per capita, GDP growth and population. Earlier, he identified GDP growth rate and trade openness as important in explaining FDI inflow to African countries. Morisset (2000) found that GDP per capita, inflation and trade openness were significant explainers of FDI flow into Africa. From the above evidence, equation (17) is augmented with inflation (INF), and GDP per capita (GPC) and a dummy variable to capture the effect of investment promotion, IPA Additionally, trade openness may be construed as the internationalisation variable in Dunning's OLI model stated in equation (2).

$$
\ln F D I_{t}=\gamma_{0}+\gamma_{1} \ln G P C_{t}+\gamma_{2} \ln E R_{t}+\gamma_{3} \ln T O P+\gamma_{4} \ln I N F_{t}+\gamma_{5} I P A+\varepsilon_{t}
$$

$A$ priori expectations with FDI: GDP per capita is positively related to FDI $\left(\gamma_{1}>0\right)$; exchange rate positively influences FDI $\left(\gamma_{5}>0\right)$; and trade openness could negatively or positively influence FDI $\left(0<\gamma_{3}<0\right)$. INF is negatively related to FDI $\left(\gamma_{4}<0\right)$ and IPA could be positively or negatively related to FDI $\left(0<\gamma_{5}<0\right)$. The IPA has a semblance of $\mathrm{O}$ in the OLI as Act 478 provides for $100 \%$ ownership if the investor s desires.

\subsection{Data}

All data were obtained from UNCTADSTAT database except otherwise specified. FDI was captured as FDI to GDP ratio. Some of the values were negative and posed problems during analysis. Following Frenkel (1976) the figure 2 was added to the series enabling the possibility of generating logarithms in the estimation procedure. GPC is USD per person; exchange rate is expressed in purchasing power parity exchange rate (2005 prices). Trade openness is computed as exports and imports in current US dollars divided by the GDP in current US dollars. Inflation is the rate of growth of the consumer price index obtained from WDI of the World Bank. From the review it was observed that GIPC effectively began operation in September, 1994. However, since the study involves annual data, 1995 was considered as the beginning of foreign investment promotion. Therefore GIPC was recognised as 1 from 1995 to 2009 and 0 before 1995.

\section{Results and Discussion}

\subsection{Plot of FDI over Time}

From a level of 5 in 1970, FDI-to-GDP ratio dropped till 1974 (Figure 1). The ratio was generally flat between 1978 and 1993. The ratio began to tick significantly from 1993. This year marked the return to multi-party democracy. For most part of 1993 to 2009, the ratio was between 3 and 6. The exceptions were 1994 and 2006-2009. These highs are appreciable as the denominator of the ratio was rising as well. Thus growths in the ratio point to rates of increase of FDI greater than GDP growth rate. These periods of high ratios also correspond to the period during which the investment regulation agency was transformed into an investment promotion organisation.

\subsection{Unit Roots Tests and Cointegration Test}

As is the case with time series data, there is a high likelihood of unit roots in the data series. Following Augmented Dickey-Fuller test with intercept, and Phillips-Perron tests, the series were subjected to test of unit roots. Table 1 shows the results. Except logarithm of INF, all other variables were stationery after first differencing. Earlier, exchange rate was captured as local currency unit to USD. The unit root test showed the series was integrated of order 2. This would create problems with cointegration even with Autoregressive Distributed Lag (ARDL) model. Therefore, another rendition of exchange rate, purchasing power parity exchange rate was used which turned out to be I (1).

The presence of I (0) series among the variables precludes the effective use of Johansen's method of cointegration. The absence of I (2) series among the variables then favoured the use of ARDL approach to assess the presence of 
cointegration among the variables. The results of the ARDL model estimation is presented in table 2. The ARDL bounds test showed that the calculated $F$-statistic of 14.8208 exceeded the upper bounds of the critical values for both $5 \%$ and $1 \%$ probability levels. The null hypothesis of no cointegration of the variables is rejected in favour of the alternative that there is cointegration. The selected ARDL model based on Schwarz Bayesian Criteria (SBC) is presented in Table 3. The diagnostic test in table 4 shows that there is no serial correlation of error terms, no heteroscedasticity and the appropriate functional form was specified. The LM version of the normality test however showed non-normality. Since non-normality is principally required for forecasting which is not aimed at in the study, the statistically significant non-noramilty is ignored.

\subsection{Short Run Empirical Model}

With fairly good model statistics; R squared and adjusted R squared greater than $50 \%$, and statistically significant $F$ statistic of 7.99, the model is fit for inferences to be drawn from it. In the short run model (Table 2) inflation and trade openness are statistically significantly different from zero $5 \%$ and $10 \%$ respectively. In the short run, $1 \%$ increase in trade openness will induce $1.5 \%$ increase in FDI inflow into Ghana's economy. Similarly, a $1 \%$ decrease in inflation will induce a $2.11 \%$ increase in FDI inflow. This concurs with the findings of Morisset (2000, 2003), Dah \& Khadijah (2010) and Djokoto (2012). The key variable, GIPC is not statistically distinguishable from zero. The statistical insignificance is in disagreement with the findings of Harding and Javorcikr (2007) and Harding and Javorcik (2011).

\subsection{Long Run Empirical Model}

Following the existence of cointegration among the variables, the long-run coefficients of equation (18) were estimated (Table 5). The coefficients of inflation and exchange rate conformed to a priori expectations, so did those of GIPC, trade openness and GPC. In respect of statistical significance, those of exchange rate and GIPC were not significant whilst the coefficients of trade openness, inflation and GDP per capita were statistically distinguishable from zero. Therefore, trade openness and GDP per capita exerts a significant positive effect on FDI inflow into Ghana's economy. This result is in line with the findings of Morisset (2000, 2003), Dah \& Khadijah (2010) and Djokoto (2012). The natural logarithm expression of the model implies that the coefficients are elasticities. A $1 \%$ increase in trade openness will lead to a $3.67 \%$ increase in FDI inflow. Also, a $1 \%$ increase in GDP per capita will induce a $3.04 \%$ increase in FDI inflow to Ghana. The high elasticity figures show the relative importance of these variables in determination of FDI inflow to Ghana. Ghana has traditionally been involved in trade especially exports of cocoa. Imports have grown since import substitution policies were relaxed in the mid-1980s. Thus, increase in trade openness in the presence of increasing FDI inflow confirms this result. In respect of GDP per capita, a study growth of the country's economy has been witnessed over the period and in the presence of increases in FDI inflow, this result is to be expected.

Inflation is significantly, negatively related to FDI inflow. A $1 \%$ decrease in inflation will exert a $2.11 \%$ increase in FDI inflow. Decreased inflation implies price stabilisation. This creates conducive environment for planning. Decreased inflation also shows that the local currency value of investment will not diminish. The exchange rate variable is negative but statistically indistinguishable from zero. The non-discernible effect of exchange rate on FDI inflow into Ghana concurs with the conclusions of Nyarko et al (2011).

In respect of the focus variable of the study, though positive, it is statistically insignificant. This means the transformation of the investment institution into GIPC has not had a significant singular contribution to FDI inflow into Ghana. This is contrary to the findings of Morisset (2003), Harding and Javorcikr (2007) and Harding and Javorcik (2011). The disagreement may be due to the coverage of data, whilst Morisset (2003) used data on survey for only 2001 across 58 countries, the current paper examined a time series model for a country, Ghana. A better comparative study would have been a time series study for other countries or panel of countries spanning 1970 to 2008. Also, the period of existence of GIPC barely exceeds a quarter of the study period.

\section{Conclusions and Recommendations}

The paper set out to investigate the effect of the establishment of GIPC on FDI inflow into Ghana. The control variables, inflation and trade openness were statistically significant in the short run. Whilst inflation exerted a negative effect on FDI inflow, trade openness positively induced FDI inflow. GDP per capita and exchange rate did not statistically significantly influence FDI inflow in the short run. In respect of the key variable GIPC, in the short run, there was a positive but statistically insignificant effect in FDI inflow. In the long run, the results show that in spite of a positive relationship between GIPC and FDI inflow, this relationship was statistically insignificant as in the short run. Exchange rate also did not impact on FDI inflow into Ghana. Other macroeconomic variables, GDP per capita, trade openness and inflation were significant in explaining FDI inflow into Ghana with inflation exerting 
a negative effect in the long run whilst the other statistically significant variables exerting a positive effect in the long run.

The above results show that macroeconomic management is more important in inducing FDI inflow into Ghana than investment promotion agency per se. Greater effort must be made at macroeconomic management, namely, reducing inflation, increasing trade and growing the size of the economy. Given the insignificant but positive relationship of GIPC with FDI inflow, GIPC may play complementary or secondary roles to macroeconomic management. Specifically, the macroeconomic variables will attract FDI whilst GIPC provides the needed support services to the investors.

More specific country studies within a time series environment as well as developing country studies within a panel environment will be important in elucidating on the impact of investment promotion on FDI inflows.

\section{References}

Aryeetey, E., \& Baah-Boateng, W. (2007). Growth, investment and employment in Ghana. Working Paper No. 80. Policy Integration Department, International Labour Office, Geneva. Retrieved from http://www.oit.org/wcmsp5/groups/public/---dgreports/---integration/documents/publication/wcms_085043.pdf

Aryeetey, E., Osei, T. A-A. B., Twerefou, D., Laryea, A., Baah-Boateng, W., Turkson, E., \& Codjoe, E. (undated). Employment and poverty in Ghana Retrieved from: http://scholar.googleusercontent.com/scholar?q=cache:eHgK_GnZUo4J:scholar.google.com/\&hl=en\&as_sdt=0,5.

Bajo-Rubio, O., \& Sosvilla-Rivero, S. (1994). An econometric analysis of foreign direct investment in Spain. Southern Economic Journal, 6, 104-20. http://dx.doi.org/10.2307/1060133

Barthel, F., Busse, M., \& Osei, R. (2008). The characteristics and determinants of FDI in Ghana. Hamburg Institute of International Economics (HWWI), Germany. Retrieved from: http://www.hwwi.org/fileadmin/hwwi/Publikationen/Research/Paper/Weltwirtschaft/HWWI_Research_Paper_2-15. pdf.

Cotton, L., \& Ramachandran, V. (2001). Foreign direct investment in emerging economies: Lessons from sub-Saharan Africa. Discussion Paper No. 2001/82. World Institute for Development Economics Research, United Nations University.

Dah, F. K., \& Khadijah, M. S. (2010). The contribution of oil to the economic development of Ghana: The role of foreign direct investments (FDI) and government policies. (Master Dissertation in International Business 15 ECT). Department of Economics and Informatics, University West.

de Mello Jr., L. R. (1997). Foreign direct investment in developing countries and growth: A selective survey. Journal of Development Studies, 34 (1), 1-34. http://dx.doi.org/10.1080/00220389708422501

Djokoto, J. G. (2012). Does causal relationships exist between external trade and foreign direct investment flow to agriculture in Ghana? International Journal of Business Management, 7(1), 179-193. http://dx.doi.org/10.5539/ijbm.v7n2p179

Dunning, J. H. (1977). Trade, location of economic activity and the multinational enterprise. In Ohlin, B., Hesselborn, P. O., \& Wijkman, P. M. (Eds.), The international allocation of economic activity (pp. 395-418). London: Macmillan.

Dunning, J. H. (1988). The eclectic paradigm of international production: A restatement and some possible extensions. Journal of International Business Studies, 19 (1), 1-31. http://dx.doi.org/10.1057/palgrave.jibs.8490372

Dunning, J. H. (1993). Multinational Enterprises and the Global Economy. London: Addison-Wesley Publishers.

Dunning, J. H. (2001). The eclectic (OLI) paradigm of international production: Past, present and future. Journal of the Economics of Business, 8 (2), 173-190. http://dx.doi.org/10.1080/13571510110051441

Frenkel, J. A. (1976). A monetary approach to the exchange rate: Doctrinal aspects and the empirical evidence. The Scandinavian Journal of Economics, 78 (2), 200-224. http://dx.doi.org/10.2307/3439924

GIPC (2011). Ghana Investment Promotion Centre. Retrieved from: http://www.gipc.org.gh/pages.aspx?id=17

Harding, T., \& Javorcikr, B. S. (2007). Developing economies and international investors: Do investment promotion agencies bring them together? Policy Research Working Paper 4339. The World Bank Development Research Group, Trade Team, August 2007. 
Harding, T., \& Javorcik, B. S. (2011). Roll out the red carpet and they will come: Investment promotion, information asymmetries and FDI inflows. Economic Journal, 121(557), 1445-1476 http://dx.doi.org/10.1111/j.1468-0297.2011.02454.x

Head, C. K., Ries, J. C., \& Swenson, D. L. (1994). The attraction of foreign manufacturing investments: Investment promotion and agglomeration economies. Regional Science and Urban Economics, 29, 197-218. http://dx.doi.org/10.1016/S0166-0462(98)00029-5

Kim, S-H., Pickton, T. S., \& Gerking, S. (2003). Foreign direct investment: agglomeration economies and returns to promotion expenditures. The Review of Regional Studies, 33 (1), 61-72.

Marchant, M. A., Cornell, D. N., \& Koo, W. (2002). International trade and foreign direct investment: substitutes or complements?. Journal of Agricultural and Applied Economics, 34(2), 289-302.

Morisset, J. (2000). Foreign direct investment in Africa: Policies matter. Transnational Corporations, 9(2), 107-25.

Morisset, J. (2003). Does a country need a promotion agency to attract foreign direct investment? World Bank Policy Research Working Paper, 3028.

Ndikumana, L. (2003). Capital flows, capital account regimes, and foreign exchange rate regimes in Africa, in: United Nations Conference on Trade and Development (UNCTAD) Management of capital flows: Comparative experiences and implications for Africa, UNCTAD, Geneva, pp.313-384.

Nyarko, P. A., Nketiah-Amponsah, E., \& Barnor, C. (2011). Effects of exchange rate regimes on FDI inflows in Ghana. International Journal of Economics and Finance, 3(3), 277-286. http://dx.doi.org/10.5539/ijef.v3n3p277

Ögütçü, M. (2002). Good governance and best practices for investment policy and promotion. Paper presented at the UNCTAD Workshop on Efficient and Transparent Investment Promotion Practices: The Case of LDCs. Geneva, 6-7 June 2002.

Tsikata, G. K., Asante, Y., \& Gyasi, E. M. (2000). Determinants of foreign direct investment in Ghana. London, UK: Overseas Development Institute.

UNCTAD (2001). The World of investment promotion at a glance: A Survey of investment promotion practices. United Nations Conference on Trade and Development, United Nations Advisory Studies number 17, UNCTAD/ITE/IPC/3.

UNCTAD (2002). Foreign direct investment statistics.

UNCTAD (2003). Investment policy review: Ghana (New York and Geneva): United Nations.

UNECA (2006). Economic report on Africa: Capital flows and development financing in Africa. United Nations Economic Commission for Africa. UNECA, Addis Ababa.

Wells, L. T., \& Wint, A. G. (2000). Marketing a Country, Occasional Paper, 13. Foreign Investment Advisory Service. US.

Table 1. Stationarity Test

\begin{tabular}{|c|c|c|c|c|}
\hline & \multicolumn{2}{|c|}{ Augmented Dickey-Fuller Test } & \multicolumn{2}{c|}{ Phillips-Perron Test } \\
\hline Variable & $\mathrm{I}(0)$ & $\mathrm{I}(1)$ & $\mathrm{I}(0)$ & $10.87723^{* * *}$ \\
\hline LnFDI & 2.562194 & $9.453605^{* * *}$ & 2.580648 & $6.082766^{* * *}$ \\
\hline GIPC & 0.716350 & $6.082763^{* * *}$ & 0.716350 & $4.768079^{* * *}$ \\
\hline LnGPC & 0.192309 & $4.814159^{* * *}$ & 0.192309 & $9.084867^{* * *}$ \\
\hline LnINF & $4.034856^{* * *}$ & $5.656673^{* * *}$ & $4.014591^{* * *}$ & $7.616907^{* * *}$ \\
\hline LnTOP & 2.337252 & $7.574162^{* * *}$ & 2.183984 & $3.425210^{* *}$ \\
\hline LnPPPER & 0.571499 & $3.545112^{* *}$ & 0.490893 & \\
\hline
\end{tabular}

Note: ${ }^{* *}$ means significance at $5 \%$; and ${ }^{* * *}$ means significance at $1 \%$. 
Table 2. Error Correction Representation for the Selected ARDL Model: ARDL $(0,1,0,0,0,1)$ Selected Based on Schwarz Bayesian Criterion

\begin{tabular}{|c|c|c|c|c|}
\hline \multicolumn{5}{|c|}{ Dependent variable is dLFDI, 37 observations used for estimation from 1972 to 2008} \\
\hline Regressor & Coefficient & \multicolumn{2}{|c|}{ Standard Error } & T-Ratio \\
\hline dLnTOP & .35850 & \multicolumn{2}{|c|}{0.20302} & $1.7658^{*}$ \\
\hline dLnPPPER & -.010840 & \multicolumn{2}{|l|}{0.031992} & -0.33885 \\
\hline dLnINF & -.16885 & \multicolumn{2}{|l|}{0.079982} & $-2.1111^{* *}$ \\
\hline dGIPC & .10402 & \multicolumn{2}{|l|}{0.20866} & 0.49852 \\
\hline dLnGPC & -.55699 & \multicolumn{2}{|l|}{0.40337} & -1.3808 \\
\hline $\mathrm{d} \gamma_{0}$ & -2.7427 & \multicolumn{2}{|l|}{1.7422} & -1.5743 \\
\hline ecm $(-1)$ & -1.0000 & \multicolumn{2}{|l|}{0.00} & *NONE* \\
\hline \multicolumn{2}{|c|}{ R-Squared } & \multicolumn{3}{|c|}{0.62336} \\
\hline \multicolumn{2}{|c|}{ R-Bar-Squared } & \multicolumn{3}{|c|}{0.53245} \\
\hline \multicolumn{2}{|c|}{ S.E. of Regression } & \multicolumn{3}{|c|}{0.26654} \\
\hline \multicolumn{2}{|c|}{ F-stat. $\mathrm{F}(6,30)$} & \multicolumn{3}{|c|}{$7.9994^{* * *}$} \\
\hline \multicolumn{2}{|c|}{ Mean of Dependent Variable } & \multicolumn{3}{|c|}{0.02899} \\
\hline \multicolumn{2}{|c|}{ S.D. of Dependent Variable } & \multicolumn{3}{|c|}{0.38980} \\
\hline \multicolumn{2}{|c|}{ Residual Sum of Squares } & \multicolumn{3}{|c|}{2.0602} \\
\hline \multicolumn{2}{|c|}{ Equation Log-likelihood } & \multicolumn{3}{|c|}{0.92949} \\
\hline \multicolumn{2}{|c|}{ Akaike Info. Criterion } & \multicolumn{3}{|c|}{-7.0705} \\
\hline \multicolumn{2}{|c|}{ Schwarz Bayesian Criterion } & \multicolumn{3}{|c|}{-13.5142} \\
\hline \multicolumn{2}{|c|}{ DW-statistic } & \multicolumn{3}{|c|}{2.2975} \\
\hline \multicolumn{5}{|c|}{ Testing for existence of a level relationship among the variables in the ARDL model } \\
\hline F-statistic & $95 \%$ Lower Bound & $95 \%$ Upper Bound & $90 \%$ Lower Bound & $90 \%$ Upper Bound \\
\hline 14.8208 & 2.4189 & 3.8105 & 1.9818 & 3.2181 \\
\hline W-statistic & $95 \%$ Lower Bound & $95 \%$ Upper Bound & $90 \%$ Lower Bound & $90 \%$ Upper Bound \\
\hline 88.9250 & 14.5133 & 22.8627 & 11.8906 & 19.3089 \\
\hline
\end{tabular}

Note: ${ }^{*}$ means significance at $10 \% ;{ }^{* *}$ means significance at $5 \%$; and ${ }^{* * *}$ means significance at $1 \%$.

Table 3. Estimated Autoregressive Distributed Lag Estimates: ARDL $(0,1,0,0,0,1)$ Selected Based on Schwarz Bayesian Criterion

\begin{tabular}{|c|c|c|c|}
\hline \multicolumn{4}{|c|}{ Dependent variable is LFDI, 37 observations used for estimation from 1972 to 2008} \\
\hline Regressors & Coefficient & Standard Error & T-Ratio \\
\hline LnTOP & 0.35850 & 0.20302 & $1.7658^{*}$ \\
\hline $\operatorname{LnTOP}(-1)$ & 0.41128 & 0.22513 & $1.8269^{*}$ \\
\hline LnPPPER & -0.010840 & 0.031992 & -0.33885 \\
\hline LnINF & -0.16885 & 0.079982 & $-2.1111^{* *}$ \\
\hline GIPC & 0.10402 & 0.20866 & .49852 \\
\hline LnGPC & -0.55699 & 0.40337 & -1.3808 \\
\hline $\operatorname{LnGPC}(-1)$ & 1.3806 & 0.45904 & $3.0076^{* * *}$ \\
\hline$\gamma_{0}$ & -2.7427 & 1.7422 & -1.5743 \\
\hline \multicolumn{2}{|c|}{ R-Squared } & 0.71379 & \\
\hline \multicolumn{2}{|c|}{ R-Bar-Squared } & 0.64471 & \\
\hline \multicolumn{2}{|c|}{ S.E. of Regression } & 0.26654 & \\
\hline \multicolumn{2}{|c|}{ F-stat. F(7, 29) } & $10.3323^{* * *}$ & \\
\hline \multicolumn{2}{|c|}{ Mean of Dependent Variable } & 1.1329 & \\
\hline \multicolumn{2}{|c|}{ S.D. of Dependent Variable } & 0.44716 & \\
\hline \multicolumn{2}{|c|}{ Residual Sum of Squares } & 2.0602 & \\
\hline \multicolumn{2}{|c|}{ Equation Log-likelihood } & 0.92949 & \\
\hline \multicolumn{2}{|c|}{ Akaike Info. Criterion } & -7.0705 & \\
\hline \multicolumn{2}{|c|}{ Schwarz Bayesian Criterion } & -13.5142 & \\
\hline \multicolumn{2}{|c|}{ DW-statistic } & 2.2975 & \\
\hline
\end{tabular}

Note: ${ }^{*}$ means significance at $10 \% ;{ }^{* *}$ means significance at $5 \%$; and ${ }^{* * *}$ means significance at $1 \%$. 
Table 4. Diagnostic Tests of Autoregressive Distributed Lag Model

\begin{tabular}{|c|c|c|}
\hline \multicolumn{1}{|c|}{ Test Statistic } & LM Version & F Version \\
\hline Lagrange multiplier test of residual serial correlation & CHSQ (1) $=0.98049$ & $\mathrm{~F}(1,28)=0.76219$ \\
\hline $\begin{array}{c}\text { Ramsey's RESET test using the square of the fitted values testing for } \\
\text { functional Form }\end{array}$ & CHSQ (1) $=0.25535$ & $\mathrm{~F}(1,28)=0.19458$ \\
\hline Normality test based on a test of skewness and kurtosis of residuals & CHSQ (2) $=5.4023^{*}$ & Not applicable \\
\hline $\begin{array}{c}\text { Heteroscedasticity test based on the regression of squared residuals } \\
\text { on squared fitted values }\end{array}$ & CHSQ (1) $=0.11958$ & $\mathrm{~F}(1,35)=0.11348$ \\
\hline
\end{tabular}

Note: ${ }^{*}$ means significance at $10 \%$.

Table 5. Estimated Long Run Coefficients Using the ARDL Approach: ARDL $(0,1,0,0,0,1)$ Selected Based on Schwarz Bayesian Criterion

\begin{tabular}{|c|c|c|c|}
\hline \multicolumn{4}{|c|}{ Dependent variable is LFDI, 37 observations used for estimation from 1972 to 2008 } \\
\hline Regressor & Coefficient & Standard Error & T-statistic \\
\hline LnTOP & 0.76978 & 0.20952 & $3.6740^{* * *}$ \\
\hline LnPPPER & -0.010840 & 0.031992 & -0.33885 \\
\hline LnINF & -0.16885 & 0.079982 & $-2.1111^{* *}$ \\
\hline GIPC & 0.10402 & 0.20866 & 0.49852 \\
\hline LnGPC & 0.82363 & 0.27056 & $3.0441^{* * *}$ \\
\hline$\gamma_{0}$ & -2.7427 & 1.7422 & $-1.5743^{* * *}$ \\
\hline
\end{tabular}

Note: ${ }^{* *}$ means significance at $5 \%$; and ${ }^{* * *}$ means significance at $1 \%$.

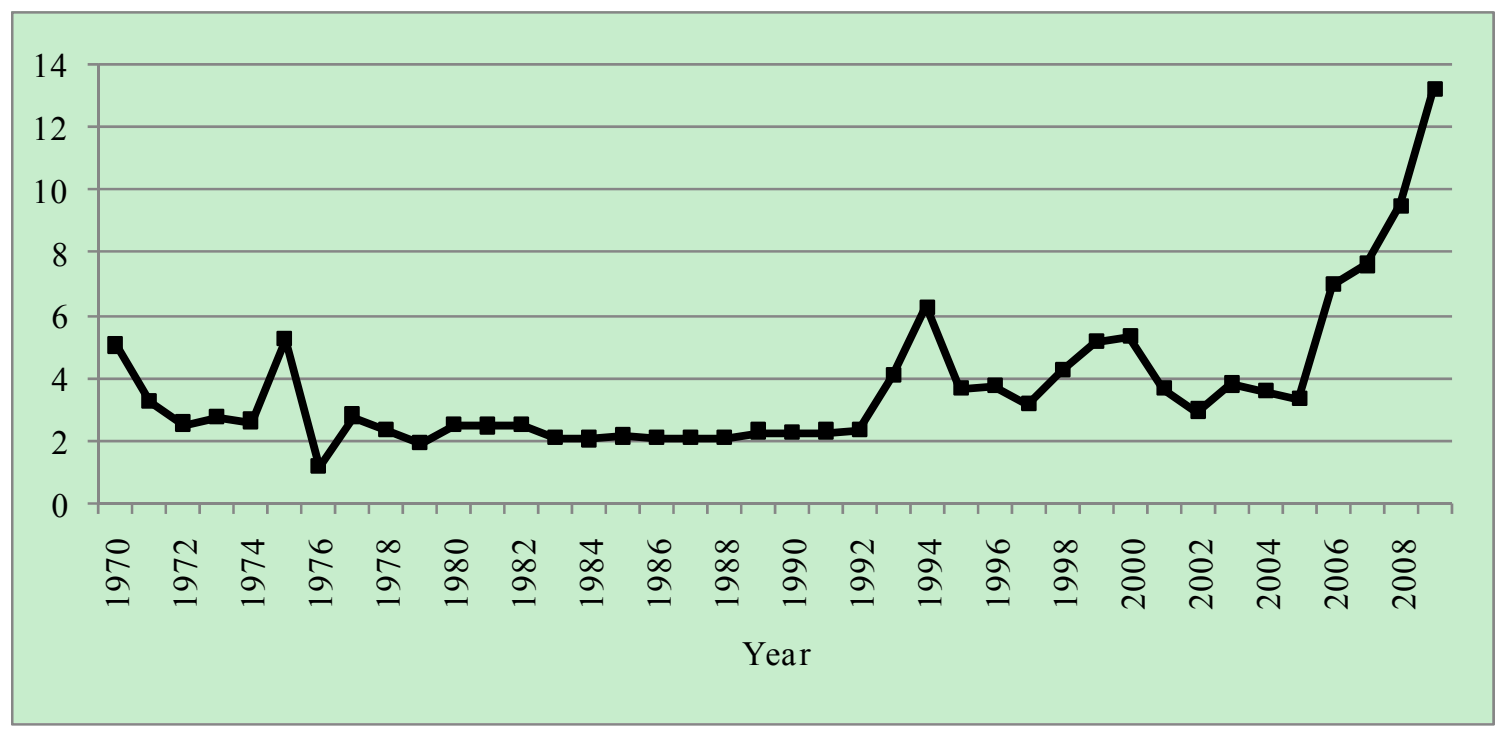

Figure 1. FDI to GDP Ratio for Ghana, 1970-2009 